\title{
Passiflora edulis Growth Under Different Water Regimes
}

\author{
Layanara Oliveira Faria ${ }^{1}$, Ane Gabriele Vaz Souza ${ }^{1}$, Fernanda Pires de Alvarenga ${ }^{1}$, \\ Frederico da Costa Mendes Silva ${ }^{1}$, Jaime Santos do Rego Junior ${ }^{1}$, Víctor Alves Amorim ${ }^{1}$, \\ Larissa Pacheco Borges ${ }^{1} \&$ Fábio Santos Matos ${ }^{1}$ \\ ${ }^{1}$ State University of Goiás, Ipameri University Unit, Brazil \\ Correspondence: Fábio Santos Matos, State University of Goiás, Ipameri University Unit, GO 330, Km 241, \\ Ring Road, University Sector, Zip Code: 75780-000, Brazil. Tel: 55-64-3491-1556. E-mail: \\ fabio.agronomia@hotmail.com
}

Received: January 19, 2020

Accepted: February 23, 2020

Online Published: March 15, 2020

doi:10.5539/jas.v12n4p231

URL: https://doi.org/10.5539/jas.v12n4p231

\begin{abstract}
The present study aimed to evaluate the initial growth of Passiflora edulis plants under water deficit and inundation. The work was carried out in a greenhouse covered with transparent plastic in pots with a capacity of five liters and filled with $5 \mathrm{~kg}$ of substrate composed of oxisol, sand and cattle manure in the proportion of 3:1:1, respectively. The experimental design used was completely randomized, with seven treatments and five repetitions; 30 days after emergence, the plants were irrigated with water equivalent to $25 \%, 50 \%, 75 \%, 100 \%$, $125 \%, 150 \%$ and $175 \%$ of the pot capacity and the analyzes were performed on the $52 \mathrm{nd}$ day. The P. edulis plants under limitation and excess water showed high stomatal sensitivity to reduce the water. In addition, under water deficit, the plants showed bigger root growth to maximize water absorption from the soil, but in both stresses the plants demonstrated reduced vegetative growth, that implies retarded establishment, thus, demonstrating an average susceptibility to water deficit and inundation.
\end{abstract}

Keywords: drought, oxygen deficit, vegetal establishment

\section{Introduction}

The yellow passion fruit (Passiflora edulis Sims) is the most cultivated in the world and the most commercially cultivated in Brazil (Santos et al., 2017). According to IBGE (2018), Brazil is the world's largest producer of passion fruit, with emphasis on the states of Bahia, Ceará and Santa Catarina, which account for $56 \%$ of national production. Brazil produces around 555 thousand tons of passion fruit with 41 thousand cultivated hectares (Oliveira, Angonese, Gomes, \& Ferreira, 2016). The species generates around R\$ 3.667 billion for the Brazilian economy (CONAB, 2019).

The Passiflora sp. is a short cycle species compared to other perennial fruit species and thus gives a fast economic return for producers. Furthermore, there is a possibility of full utilization of the fruit, which increases the farmers' income. $P$. edulis cultivation has great social potential because of the need for labor during the cycle, mainly in crop handling, harvesting and commercialization that keeps the farmer on the farm (Oliveira, Faleiro, \& Junqueira, 2017). Brazil is the largest $P$. edulis producer and consumer in the world but there are limitations that prevent bigger production (Coelho, Azêvedo, \& Umszaguez, 2016).

Frequent extreme temperatures, drought and rains has resulted in negative impacts on the production of $P$. edulis (Madadgar, Aghakouchak, Farahmand, \& Davis, 2017). Water deficit is the most limiting stress in crop production of the species cultivated around the world, because water availability is very important for plant growth and establishment (Fracasso, Trindade, \& Amaducci, 2016). Furthermore, water deficit can promote much morphophysiological damage that affect establishment and production performance (Souza et al., 2018). According to Valdés et al. (2013), when plants identify water deficit they activate many responses to synchronize growth and molecular activities, in orde to survive. Plants can develop mechanisms to adapt to drought under water deficit which can be morphological, physiological and even anatomic (Tatagiba, Pezzopane, \& Reis, 2015). The identification of these mechanisms can explain the causes of drought resistance in plants.

Excess water in soil in inundated environments also reduce plant survival, growth and development and has consequences similar to water deficit, causing low yield, erosion of natural and cultivated biodiversity (Huang et al., 2019). In flooded conditions the oxygen concentration available for the roots decreases quickly and 
influences gas exchange and negatively affects photosynthesis, and there are also physical, chemical and microbiological changes in the soil. Passion fruit plants under flood conditions at initial growth stages show a set of physiological and anatomic changes, developing mechanisms to support oxygen depletion, by forming aerenchyma so that the species survives in pre-submerged and flood conditions (Govea et al., 2018).

Water deficit and flooding provoke morphophysiological changes in P. edulis development and may consequently affect yield. Therefore, the present study aimed to evaluate the initial growth of Passiflora edulis plants under water deficit and inundation.

\section{Material and Method}

The study was carried out between March and May 2019 in greenhouse covered with transparent plastic and shade cloth on the sides with $50 \%$ light interception at the State University of Goiás, Ipameri campus (Lat. $17^{\circ} 42^{\prime} 59.12^{\prime \prime} \mathrm{S}$, Long. $48^{\circ} 08^{\prime} 40.49^{\prime \prime}$ West, Alt. $773 \mathrm{~m}$ ), Ipameri, GO. The region has a tropical climate with dry winter and wet summer (Aw) according to the Köppen classification and $20^{\circ} \mathrm{C}$ average temperature (Alvares, Stape, Sentelhas, Gonçalves, \& Sparovek, 2013). Three seeds of P. edulis were sown in each pot, containing $5 \mathrm{~kg}$ of substrate formed by the mixture Oxisol, sand and manure 3:1:1, respectively. The chemical analysis of the soil showed the following aspects: $\mathrm{pH}\left(\mathrm{CaCl}_{2}\right) 5.4 ; 16 \mathrm{~g} \mathrm{dm}^{-3}$ organic matter; $68 \mathrm{mg} \mathrm{dm}{ }^{-3} \mathrm{P} ; 6.81 \mathrm{mmolc} \mathrm{dm} \mathrm{K}^{-3} \mathrm{~K}$ (Mehlich-1); $22 \mathrm{mmolc} \mathrm{dm}^{-3}$ (SMP Method) $\mathrm{H}+\mathrm{Al} ; 31 \mathrm{mmolc} \mathrm{dm}^{-3} \mathrm{Ca} ; 15 \mathrm{mmolc} \mathrm{dm}^{-3} \mathrm{Mg} ; 53 \mathrm{mmolc} \mathrm{dm}^{-3}$ Base Saturation; 75 mmolc dm ${ }^{-3}$ Cation Exchange Capacity and $71 \%$ Base Saturation.

At fifteen days after the emergence (DAE) of the plants, thinning was carried out, leaving one plant per pot. The experiment was set up in a completely randomized design with seven treatments and five replications. Thirty DAE the plants were irrigated with water volumes according to $25 \%, 50 \%, 75 \%, 100 \%, 125 \%, 150 \%$ and $175 \%$ substrate holding capacity. The water volume provided daily was determinated according to the holding capacity of the substrate, described by SA et al. (2017).

At 52 DAE the following analyses were carried out: number of leaves, plant height, stem diameter, biomass, root mass ratio, stem mass ratio, leaf mass ratio, photosynthetic pigments, relative water content, transpiration and chlorophyll $a$ fluorescence.

\subsection{Growth Variables}

Plant height was measured from the root-stem transition region at soil level (crown) to the tip of the stem using a graded ruler. The stem diameter was measured at the crown with a digital pachymeter. The number of leaves was obtained by counting. The roots, stems and leaves were separated and dried in an oven at $72{ }^{\circ} \mathrm{C}$ until constant dry weight and then weighed. The dry matter data were used to calculate the biomass, root mass ratio, stem mass ratio and leaf mass ratio.

\subsection{Photosynthetic Pigments}

To determine the total chlorophylls and carotenoids concentrations, $0.6 \mathrm{~mm}$ diameter leaf discs were removed from completely opened leaves and placed in test tubes containing dimethyl sulfoxide (DMSO). Then extraction was carried out in a water bath at $65{ }^{\circ} \mathrm{C}$ for one hour. Aliquots were removed for spectrophotometric reading at 480, 649 and $665 \mathrm{~nm}$. Then contents of chlorophyll a $(\mathrm{Cl} a)$, chlorophyll $\mathrm{b}(\mathrm{Cl} \mathrm{b})$ and total carotenoids (Car) were determined according to the equation proposed by Wellburn (1994).

\subsection{Relative Water Content}

To obtain the relative water content, five leaf discs of $1.2 \mathrm{~cm}$ in diameter were removed in fully expanded leaves, weighed to record the fresh mass (FM) and placed to saturate for 24 hours in petri dishes with distilled water when they were again weighed and determined the turgid mass (TM), then placed to dry at a temperature of 70 ${ }^{\circ} \mathrm{C}$ for 72 hours, after which the dry mass (DM) was obtained and then the relative water content was calculated following the equation: $[(\mathrm{FM}-\mathrm{DM}) /(\mathrm{TM}-\mathrm{DM})-100]$.

\subsection{Transpiration}

The total daily transpiration of the plant was measured by the difference in pot weight. Initially each pot was inserted into a plastic bag fixed with rubber to the plant stem, leaving only the aerial part (leaves and stem) external to the bag, then the set of plant and plastic bag were weighed (mass 01), and 24 hours later weighed again (mass 02). Total sweating was estimated by the difference between mass 01 and mass 02 (Dos Anjos et al., 2017). 


\subsection{Fluorescence}

Chlorophyll $a$ fluorescence was analyzed with six readings using a portable fluorometer JUNIOR-PAM (Walz, Germany) at 4 am with 0.3 second light saturation pulse emission of, under $0.6 \mathrm{KHz}$ frequency, at 30 days after implementing the water regimes. The fluorescence data were computed using the software, WinControl-3.

\subsection{Statistical Procedures}

The variables were submitted regression analysis using the software SigmaPlot10 (Sysstat, 2006). Multivariate analysis was carried out by multiple regression using the forward stepwise model (Sokal \& Rolf, 1995) in the STATISTICA software (Statsoft, 2007).

\section{Results}

The variables leaf mass ratio, chlorophylls and total carotenoids, photochemical quenching (qP) and non-photochemical quenching (NPQ), potential quantum efficiency of photosystem II (PSII) (Fv/Fm) and maximum PSII quantum efficiency ( $\mathrm{Fv}^{\prime} / \mathrm{Fm}$ ') did not show statistical difference related to the water regimes ( $\mathrm{P}$ $<0.05$ ) and did not fit any regression models.

The plant height and stem diameter were maximum when irrigated with water volumes of 72 and $96 \%$ of the substrate capacity, respectively (Figures 1A and 1B). The variation in the volume of water supplied promoted changes of $19 \%$ in the number of leaves (Figure 1C). The transpiration ratio showed a maximum of $76 \mathrm{~g} \mathrm{H}_{2} \mathrm{O}$ $\mathrm{day}^{-1}$ in the $118 \%$ water regime corresponding to a $250 \%$ increase compared to the lowest water regime (Figure 1D). Under excess water in the $175 \%$ substrate hold capacity, transpiration decreased $55 \mathrm{~g} \mathrm{H}_{2} \mathrm{O}_{\text {day }}{ }^{-1}$.

The RWC in the leaves showed values directly proportional to water availability described by the linear equation model (Figure 1E). The RWC increased $16 \%$ in the highest water regime compared with the lowest regime. The biomass accumulation was maximum $(9.3 \mathrm{~g})$ in plants irrigated with water volume referring to $111 \%$ of the substrate retention capacity and, from $111 \%$, the increases in water volume resulted in plants with less biomass, in a way that under excess water at $175 \%$ of the substrate retention capacity the maximum biomass was $7.3 \mathrm{~g}$ (Figure 1F). 

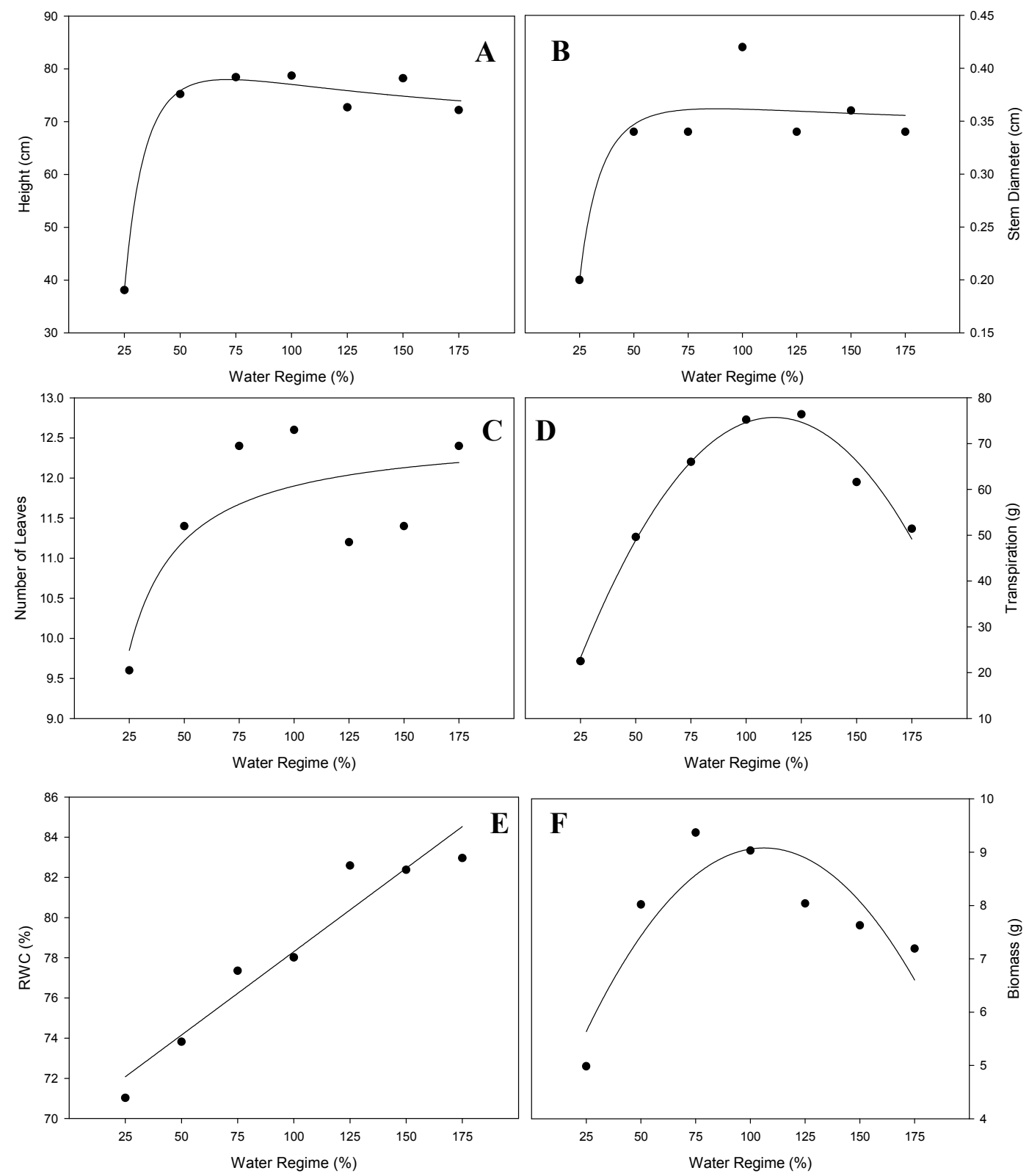

Figure 1. Regression equations for plant height $\left(\mathrm{Y}=66.479+(1646.257 / \mathrm{x})-\left(58939.26 / \mathrm{x}^{2}\right), \mathrm{R}^{2}=0.98^{* *} \mathrm{~A}\right)$, stem diameter $\left(\mathrm{Y}=0.336(4.5 / \mathrm{x})-\left(198.54 / \mathrm{x}^{2}\right) ; \mathrm{R}^{2}=0.82 * \mathrm{~B}\right)$, number of leaves $\left(\mathrm{Y}=12.58-(68.38 / \mathrm{x}) ; \mathrm{R}^{2}=\right.$ $0.63 * \mathrm{C})$, transpiration $\left(\mathrm{Y}=-10.98+1.534 \mathrm{x}-0.0065 \mathrm{x}^{2} ; \mathrm{R}^{2}=0.98^{* *} \mathrm{D}\right)$, relative water content-RWC $(\mathrm{Y}=69.99$ $\left.+0.0831 \mathrm{x} ; \mathrm{R}^{2}=0.92^{* *} \mathrm{E}\right)$ and biomass $\left(\mathrm{Y}=3.185+0.111 \mathrm{x}-0.0005 \mathrm{x}^{2} ; \mathrm{R}^{2}=0.78^{*} \mathrm{~F}\right)$ in Passiflora edulis plants irrigated with different water regimes

The Initial fluorescence $\left(\mathrm{F}_{0}\right)$ decreased linearly with the increases in water supply, and there was a $16 \%$ difference between the extremes. The root mass ratio showed linear decrease with the increase in water (Figure 2B), whilst the stem mass ratio showed a linear increase with increased water supply. 

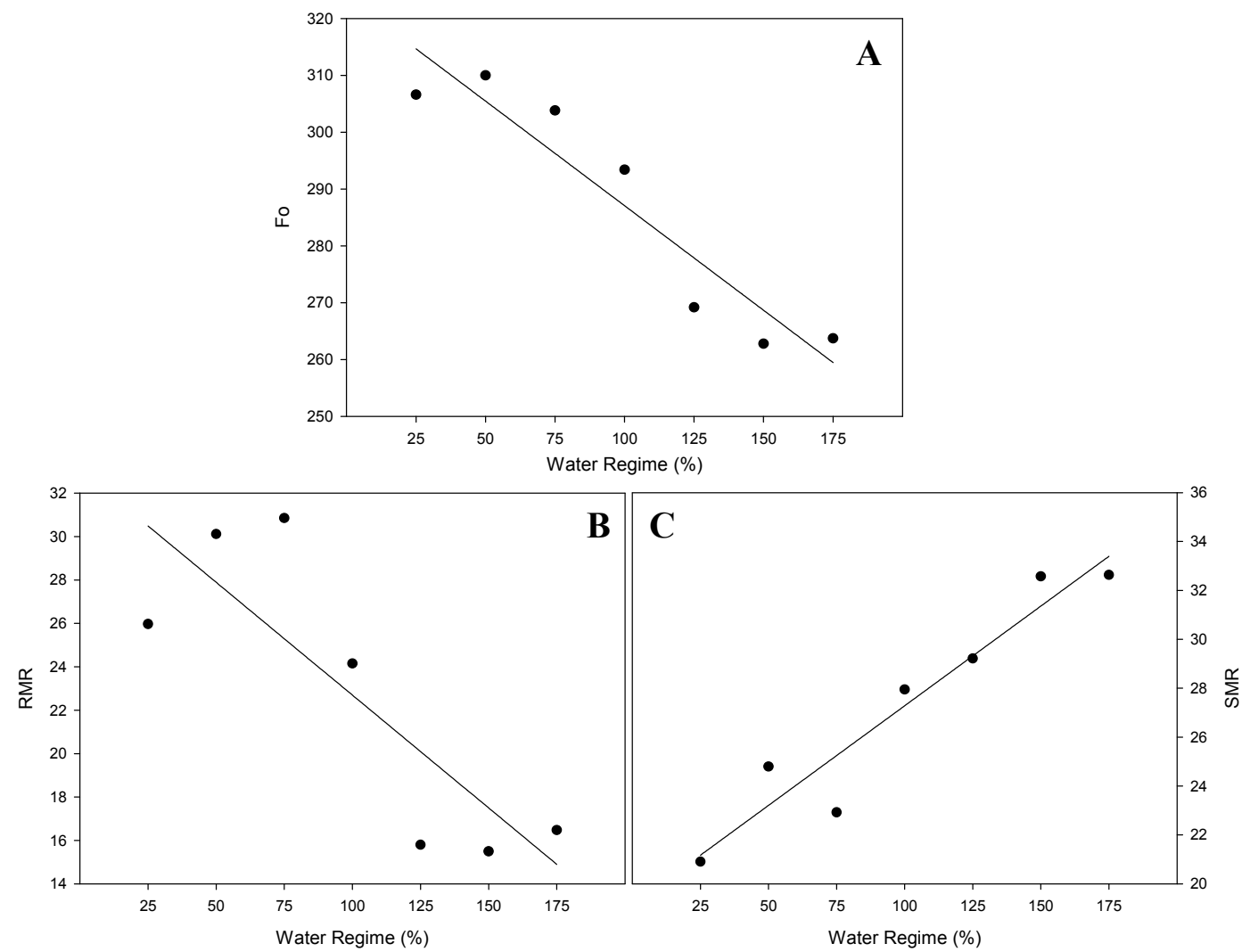

Figure 2. Regression equations for initial fluorescence $\left(F_{0}\right)\left(Y=323.87-0.3679 x ; R^{2}=0.88\right.$ A), root mass ratio $\left(\mathrm{Y}=33.09-0.104 \mathrm{x} ; \mathrm{R}^{2}=0.69^{*} \mathrm{~B}\right)$ and stem mass ratio $\left(\mathrm{Y}=19.13+0.0815 \mathrm{x} ; \mathrm{R}^{2}=0.92 * * \mathrm{C}\right)$ in Passiflora edulis plants irrigated with different water regimes

The multiple regression analysis in Table 1 shows the variables that promoted $89 \%$ biomass variation and demonstrates that plant height and number of leaves exerted positive effects in biomass increases of $P$. edulis whilst root mass ratio and maximum fluorescence $\left(\mathrm{F}_{\mathrm{m}}\right)$ represented negative effects on biomass accumulation.

Table 1. Summary of multiple regression analysis to evaluate the effects of the variables in biomass accumulation in $P$. edulis plants irrigated with different water regimes.

\begin{tabular}{|c|c|c|c|c|c|c|}
\hline \multirow{2}{*}{ Biomass (g) } & \multicolumn{2}{|c|}{$\mathrm{R}^{2}=0.89$} & \multicolumn{2}{|c|}{$F(5.29)=51.5$} & \multicolumn{2}{|c|}{$\mathrm{p}<0.0000$} \\
\hline & Beta & Std. Err. of Beta & Beta & Std. Err. of Beta & $\mathrm{t}(29)$ & p-level \\
\hline Intercept & & & -0.946 & 3.440 & -0.275 & 0.7853 \\
\hline Height & 0.995 & 0.080 & 0.111 & 0.009 & 12.469 & $0.0000 * *$ \\
\hline SMR & -0.478 & 0.078 & -0.196 & 0.032 & -6.165 & $0.0000 * *$ \\
\hline Leaves $\mathrm{N}$ & 0.240 & 0.072 & 0.384 & 0.116 & 3.317 & $0.0025 * *$ \\
\hline $\mathrm{Fm}$ & -0.155 & 0.060 & -0.002 & 0.001 & -2.583 & $0.0151 *$ \\
\hline Fv'/Fm' & 0.093 & 0.061 & 5.532 & 3.652 & 1.515 & $0.1406^{\mathrm{ns}}$ \\
\hline
\end{tabular}

Note. $\mathrm{SMR}=$ Stem Mass Ratio, $\mathrm{F}_{\mathrm{m}}=$ Maximum Fluorescence, $\mathrm{Fv}^{\prime} / \mathrm{Fm}^{\prime}=$ maximum PSII quantum efficiency.

${ }^{\mathrm{ns}}$ non-significant, ${ }^{* *}$ significant at $1 \%$ probability, ${ }^{*}$ significant at $5 \%$ probability by the $\mathrm{F}$ test.

\section{Discussion}

Variation in water availability promotes alterations in plant growth and has determinant effects on cultivated crop establishment. The present study concisely showed the importance of appropriate water supply in the initial growth of $P$. edulis plants for proper establishment according to the following discussion.

The vegetative growth of $P$. edulis plants showed a dependence of water availability in the tissues, but the decrease or increase in water availability above or below the appropriate level (100\% water regime) did not 
promote proportional variations in height, stem diameter and number of leaves. Gonçalves and Mousinho (2014) observed that different water supply in $P$. edulis interfered in seedling development and the highest water regimes provided the biggest height and stem diameter.

The data indicates the existence of a hydric buffer, possibly coming from some water storage in the stem and/or root. The present claim is confirmed by the low variation in RWC, because this variable demonstrated $4 \%$ alteration when the water supply was more or less than $50 \%$ of the appropriate level. According to Matos et al. (2014), the stem may have a storage function and buffer the water variations in leaves by supplying water quickly.

The reduction in number of leaves and growth under water deficit are adjustment strategies to tolerate low water availability, because drought promotes morphophysiological changes with intent to stimulate acclimation and tolerance to the new conditions (Matos, Freitas, Souza, Araújo, \& Rosa, 2018)

The consonance between biomass and transpiration reflects the variation in water availability in the stomatal conductance and $\mathrm{CO}_{2}$ diffusion for photosynthesis, because as the water volume provided was increased, the stomata opened, resulting in higher $\mathrm{CO}_{2}$ influx and water efflux with consequent increase in photosynthesis, and increases in the biomass and transpiration with maximum point at $111 \%$ and $118 \%$ water regimes, respectively. According to Souza et al. (2015), transpiration decreases under low water viability indicating tolerance to water deficit; but other mechanisms are needed to ratify tolerance. The $P$. edulis species is adapted to drought for short periods through efficient stomatal regulation (Souza et al., 2017). The reduction of perspiration under excess water in irrigation is indicative of efficient stomatal control of $P$. edulis.

The increments in water availability above the appropriate level resulted in decreases in transpiration and biomass, so that, in the $175 \%$ water regime transpiration and biomass showed decreases of about $28 \%$ and $22 \%$, respectively, according to the maximum point. The results indicated that $P$. edulis plants are moderately sensitive to water excess in the soil. According to Souza, Bastos, Cardoso and Pereira (2018), excess water supply can lead to hypoxia in plants that restricts biomass accumulation. Under excess water in the soil there are fewer spaces designated to gases and, if it persists, inhibition of respiration, cytosol $\mathrm{pH}$ reduction and decreased aquaporin activity is common, according to Taiz and Zeiger (2017).

The $\mathrm{F}_{0}$ decrease with the increments in water regime and the inversely proportional relationship between $\mathrm{F}_{\mathrm{m}}$ and biomass are indicatives of efficient photoprotection mechanisms of the photosynthesis machinery with the water status modifications in $P$. edulis. The variations in photosynthesis fluorescence indicate changes in plant photosynthetic capacity under stress. According to Suassuna et al. (2010), the photochemical efficiency of the passion fruit is altered with changes in substrate moisture.

Under water deficit the shoot growth precedes the reduction in photosynthesis and part of the assimilates are moved to the roots, so that a greater partitioning of assimilates to the roots justifies a greater mass in this area that operates as a soil moisture sensor. The RMR increase with increments in water supply refers to the need for changes in hydraulic conductivity in the plants, because under water deficit the phloem sap flux is low compared to the flux in plants with high water volumes. According to Taiz and Zeiger (2017), a slight drying of the soil results in the main root growth and lateral root formation.

The decreases in transpiration and biomass under water deficit and flooding are enough to prove that drought and excess water reduce the vegetative growth and disturb the establishment of $P$. edulis plants.

\section{Conclusions}

$P$. edulis plants under water restriction and excess water in the soil showed high stomatal conductance to reduce water loss in addition, under water deficit the plants demonstrated greater root system growth to maximize soil solution absorption, but both stresses exhibited reduction in vegetative growth which led to delayed establishment, thus showing an average susceptibility to drought and flooding.

\section{References}

Alvares, C. A., Stape, J. L., Sentelhas, P. C., Gonçalves, J. L. M., \& Sparovek, G. (2013). Köppen’s climate classification map for Brazil. Meteorologische Zeitschrift, 22(6), 711-728. https://doi.org/10.1127/ 0941-2948/2013/0507

Coelho, E. M., Azêvedo, L. C., \& Umszaguez, M. (2016). Fruto do Maracujá: Importância Econômica e Industrial, Produção, Subprodutos e Prospecção Tecnológica. Cadernos de Prospecção, 9(3), $347-361$. https://doi.org/10.9771/cp.v9i3.16637 
CONAB (Companhia Nacional de Abastecimento). (2019). Retrieved April 5, 2019, from https://www.conab. gov.br/info-agro/hortigranjeiros-prohort

Fracasso, A., Trindade, L. M., \& Amaducci, S. (2016). Drought Stress Tolerance Strategies Revealed by RNA-Seq in Two Sorghum Genotypes With Contrasting WUE. BMC Plant Biology, 16(115), 01-18. https://doi.org/10.1186/s12870-016-0800-x

Gonçalves, M. P. G., \& Mousinho, F. E. P. (2014). Efeito de lâminas de irrigação sobre o crescimento de mudas de maracujá. II Inovagri International Meeting (pp. 1315-1321). https://doi.org/10.12702/ii.inovagri. 2014-a176

Govêa, K. P., Neto, A. R. C., Resck, N. M., Moreira, L. L., Júnior, V. V., Pereira, F. L., ... Souza, T. C. (2018). Morpho-anatomical and physiological aspects of Passilora edulis Sims (passion fruit) subjected to flooded conditions during early developmental stages. Biotemas, 31(3), 15-23. https://doi.org/10.5007/2175-7925. $2018 \mathrm{v} 3 \ln 3 \mathrm{p} 15$

Huang, J., Hu, T., Yasir, M., Gao, Y., Chen, C., Zhu, R., ... Yang, J. (2019). Root growth dynamics and yield responses of rice (Oryza sativa L.) under drought_-Flood abrupt alternating conditions. Environmental and Experimental Botany, 157, 11-25. https://doi.org/10.1016/j.envexpbot.2018.09.018

IBGE (Instituto Brasileiro De Geografia E Estatística). (2018). Produção Agrícola Nacional, 2018. Retrieved June 15, 2019, from https://sidra.ibge.gov.br/tabela/5457\#resultado

Madadgar, S., Aghakouchak, A., Farahmand, A., \& Davis, S. J. (2017). Probalistic Estimates of Drought Impacts on Agricultual Production. Geophysical Research Letters, 44(15), 7799-7807. https://doi.org/10.1002/ 2017GL073606

Matos, F. S., Freitas, I. A. S., Souza, B. R., Araújo Lopes, V. A., \& Rosa, V. R. (2018). Crescimento de plantas de tectona grandis sob restrição hídrica. Revista Agrarian, 11(39), 14-21. https://doi.org/10.30612/agrarian. v11i39.5284

Matos, F. S., Torres Junior, H. D., Rosa, V. R., Santos, P. G. F., Borges, L. F. O., Ribeiro, R. P., ... Cruvinel, C. K. L. (2014). Estratégia morfofisiológica de tolerância ao déficit hídrico de mudas de pinhão manso. Magistra, 26(1), 19-27.

Oliveira, D. A., Angonese, M., Gomes, C., \& Ferreira, S. R. S. (2016). Valorization of passion fruit (Passiflora edulis sp.) by-products: sustainable recovery and biological activities. Journal of Supercritical Fluids, 111, 55-62. https://doi.org/10.1016/j.supflu.2016.01.010

Oliveira, J. S., Faleiro, F. G., \& Junqueira, N. T. V. (2017). Importância dos maracujás (Passiflora L. spp.) e seu uso comercial. Revista RG News, 3(3), 72-81.

Sá, F. V. S., Mesquita, E. F., Souza, F. M., Mesquita, S. O., Paiva, E. P., \& Silva, A. M. (2017). Depleção de água e composição do substrato na produção de mudas de melancia. Revista Brasileira de Agricultura Irrigada, 11(3), 1398-1406. https://doi.org/10.7127/rbai.v11n300550

Santos, V. A., Ramos, J. D., Laredo, R. R., Silva, F. O. R., Chagas, E. A., \& Pascal, M. (2017). Produção e qualidade de frutos de maracujazeiro amarelo provenientes do cultivo com mudas em diferentes idades. Revista de Ciências Agroveterinárias, 16(1), 33-40. https://doi.org/10.5965/223811711612017033

Sokal, R. R., \& Rolf, F. J. (1995). Biometry (2nd ed.). W. H. Freeman, New York.

Souza, P. U., Lima, L. K. S., Soares, T. L., De Jesus, O. N., Coelho Filho, M. A., \& Girardi, E. A. (2017). Biometric, physiological and anatomical responses of Passiflora spp. to controlled water deficit. Scientia Horticulturae, 229, 77-90. https://doi.org/10.1016/j.scienta.2017.10.019

Souza, R. S., Bastos, E. A., Cardoso, M. J., \& Pereira, D. R. (2018). Identification of Drought-Tolerant Corn Genotypes by Multivariate Analysis. Pesquisa Agropecuária Tropical, 48(3), 204-211. https://doi.org/ 10.1590/1983-40632018v4852122

Suassuna, J. F., De Melo, A. S., Sousa, M. S. S., Costa, F. S., Fernandes, P. D., Pereira, V. M., \& Brito, M. E. B. (2010). Desenvolvimento e eficiência fotoquímica em mudas de Híbrido de maracujazeiro sob lâminas de água. Bioscience Journal, 26(4), 566-571.

Taiz, L., \& Zeiger, E. (2017). Fisiologia vegetal (6th ed.). Porto Alegre: Artmed. 
Tatagiba, S. D., Pezzopane, J. E. M., \& Reis, E. F. (2015). Fotossíntese em Eucalyptus sob diferentes condições edafoclimáticas. Revista Engenharia na Agricultura-Reveng, 23(40), 336-345. https://doi.org/10.13083/ 1414-3984/reveng.v23n4p336-345

Valdés, A. E., Irar S., Majada, J. P., Rodríguez, A., Fernández, B., \& Pagès, M. (2013). Drought tolerance acquisition in Eucalyptus globulus (Labill.): A research on plant morphology, physiology and proteomics. Journal of Proteomics, 79, 263-276. https://doi.org/10.1016/j.jprot.2012.12.019

Wellburn, A. R. (1994). The spectral determination of chlorophylls a and b, as well as total carotenoids, using various solvents with spectrophotometers of different resolution. Journal of Plant Physiology, 144(3), 307-313. https://doi.org/10.1016/S0176-1617(11)81192-2

\section{Copyrights}

Copyright for this article is retained by the author(s), with first publication rights granted to the journal.

This is an open-access article distributed under the terms and conditions of the Creative Commons Attribution license (http://creativecommons.org/licenses/by/4.0/). 